\title{
Zinc deficiency in the West of Scotland? A dietary intake study
}

\author{
BY T. D. B. LYON \\ Department of Clinical Physics and Bio-Engineering, I West Graham Street, \\ Glasgow \\ AND H. SMITH \\ Department of Forensic Medicine, University of Glasgow, Glasgow \\ AND LAURA B. SMITH \\ The Queen's College, Glasgow, I Park Drive, Glasgow \\ (Received 16 February 1979 - Accepted 13 June 1979)
}

\begin{abstract}
1. The intake of zinc in the West of Scotland was determined by atomic absorption spectrometry, in ninety-six items of food which make up the local standard diet for I week.

2. The diet contained less $\mathrm{Zn}$ than the recommended daily allowance ((US) National Academy of Sciences, 1974). This finding either indicates the need for a revision of the suggested allowances or suggests that a change of diet is necessary.

3. The change could be made simply by the substitution of wholemeal flour for white flour. Other changes in diet were considered but they were unlikely to be acceptable. Even with changes the requirement of pregnant or lactating women would not be met. If the recommended allowances are valid these women must be deficient in $\mathrm{Zn}$.
\end{abstract}

Zinc is an essential trace element for man. Chronic $\mathrm{Zn}$ deficiency occurring locally in the Middle East has been demonstrated in man by Prasad et al. (1963) and Prasad (1966). The optimal dietary intake of $\mathrm{Zn}$ is not known. The US Food and Drug administration have recommended a daily intake of $15 \mathrm{mg}$; so far there is no recommendation as to the daily intake of biologically available $\mathrm{Zn}$. The nature of the diet influences the availability of $\mathrm{Zn}$ through the formation of non-absorbable Zn chelates (O'Dell et al. 1972; Reinhold et al. 1973; Evans \& Johnstone, 1977).

Underwood (1971), Sandstead (1973) and Schroeder (1974) consider that the $\mathrm{Zn}$ contents of various American diets are marginal and that subclinical $\mathrm{Zn}$ deficiency is widespread. The purpose of this work is to measure the dietary intake of $\mathrm{Zn}$ in the West of Scotland.

EXPERIMENTAL

Diets vary considerably reflecting different traditions and the availability of local produce. The science department at The Queen's College, Glasgow, records current trends in eating habits. This information was used to plan a typical I week menu for a family of four. Each dish was prepared in the traditional manner. The quantities were sufficient for two adults and two children aged 8 (girl) and 12 (boy) years.

The daily diet for the adult male contains an average $12.5 \mathrm{MJ}, 96 \mathrm{~g}$ protein, $140 \mathrm{~g}$ fat and $339 \mathrm{~g}$ carbohydrate. The fat content of the diet (considered to be higher than necessary) supplies over $40 \%$ of the energy.

The ingredients (ninety-six items of food spread over $7 \mathrm{~d}$ ) of each meal forming the total diet were individually homogenized, after cooking, using a Colworth 'Stomacher'. The samples were then freeze-dried and approximately I g samples of the material were analysed 
Table I. Zinc content of the West of Scotland diet*

$\begin{array}{lccc} & \begin{array}{c}\mathrm{Zn} \\ (\mathrm{mg} / \text { week })\end{array} & \begin{array}{c}\text { Energy } \\ (\mathrm{MJ} / \text { week })\end{array} & \begin{array}{c}\text { Zn:energy } \\ (\mu \mathrm{g} \mathrm{Zn} / \mathrm{kJ})\end{array} \\ \text { Meat } & 83 & 46.6 & 1.78 \\ \text { Fish (fried) } & 2.4 & 3.6 & 0.67 \\ \text { Cereals } & 58.2 & 99.9 & 0.58 \\ \text { Dairy produce } & 47 & 67.6 & 0.69 \\ \text { Vegetables } & 19.1 & 27.2 & 0.69 \\ \text { Fruit (tinned included) } & 2.3 & 8.5 & 0.26 \\ \text { Soup } & 10.6 & 12.3 & 0.86 \\ \text { Desserts } & 7.7 & 8.5 & 0.91 \\ \text { Beverages } & 7.3 & 3.2 & 2.27 \\ \text { Sugar-confectionery } & 2.0 & 22.3 & 0.09 \\ \text { Miscellaneous } & 3.5 & 3.7 & 0.96\end{array}$

* $\mathrm{Zn}$ contents of the individual items in the diet are available from the authors.

Table 2. The daily zinc intake in the Glasgow area

\begin{tabular}{|c|c|c|c|c|c|}
\hline & $\begin{array}{r}\text { Recomn } \\
\text { allo }\end{array}$ & $\begin{array}{l}\text { led daily } \\
\text { lce" }\end{array}$ & Determin & aily intake & $7 \mathrm{n}$ \\
\hline & $\begin{array}{c}\text { Energy } \\
(\mathbf{M J})\end{array}$ & $\mathrm{Zn}(\mathrm{mg})$ & $\begin{array}{c}\text { Energy } \\
(\mathrm{MJ})\end{array}$ & $\mathrm{Zn}$ (mg) & $\begin{array}{c}\text { deficiency } \\
(\%)\end{array}$ \\
\hline Adult male $(23+$ years $)$ & I $[\cdot 3$ & 15 & $12 \cdot 6$ & $10 \cdot 1$ & 33 \\
\hline Adult female $(23+$ years $)$ & $8 \cdot 4$ & 15 & $9 \cdot 5$ & $7 \cdot 6$ & 49 \\
\hline Young male ( 12 years) & $11 \cdot 7$ & 15 & $12 \cdot 1$ & $9 \cdot 7$ & 35 \\
\hline Young female ( 8 years) & $10 \cdot 0$ & 10 & $9 \cdot I$ & $7 \cdot 3$ & 27 \\
\hline Pregnant female & $+1 \cdot 3$ & 20 & - & - & - \\
\hline Lactating female & $+2 \cdot I$ & 25 & - & - & - \\
\hline
\end{tabular}

by the atomic absorption method described by Scott et al. (197I). The method involved the destruction of organic matter by dry ashing at $450^{\circ}$ followed by extraction with $6 \mathrm{M}$ hydrochloric acid. Samples of National Bureau of Standards orchard leaves, bovine liver and other reference materials were included in each batch of analyses. The $\mathrm{Zn}$ values obtained for these materials were in good agreement with the certificated or recommended values.

\section{RESULTS}

The weekly dietary intake of $\mathrm{Zn}$ for a family of four in the West of Scotland was estimated to be $243 \mathrm{mg}$ (Table 1 ). The daily family intake ranged from 20.3 to $46.1 \mathrm{mg}$ with a mean of 35 ( $\mathrm{SD} \pm \mathrm{IO}$ ). The average daily intake per person could be estimated on the basis that the diet was consumed in the following proportions: adult male $0 \cdot 29$, male child ( 12 years) $0 \cdot 28$, adult female 0.22 , female child ( 8 years) 0.21 . These values were taken from dietary information collected by The Queen's College, Glasgow. Using this information the daily intake of $\mathrm{Zn}$ could then be compared (Table 2) with the recommended daily allowance (RDA; National Academy of Sciences, 1974).

\section{DISCUSSION}

The RDA is not the daily requirement but an estimate believed to exceed the requirements of most people. Clearly, the $\mathrm{Zn}$ intakes reported here fall below the RDA for all the categories studied. This does not necessarily mean that the diet contains an insufficient amount of $\mathrm{Zn}$. The daily requirement for $\mathrm{Zn}$ is not well known, but some studies (Food and Nutrition Board, 1970; White \& Gynne, 1971) suggest a daily requirement ranging from 8 to 
$12 \mathrm{mg}$. Viewed against these values the $\mathrm{Zn}$ intake of the inhabitants of the West of Scotland is not quite adequate and it is possible that some individuals may be subclinically deficient.

If this suggestion of subclinical deficiency is accepted how can the $\mathrm{Zn}$ intake of the population be increased without increasing the energy value of the diet? The measurement that must be considered in trace-element nutritional studies is the amount of biologically available element/J. In general the biological availability is not known, so that the total amount of the element/ $\mathrm{J}$ must be used; nevertheless, this is more useful than the concentration of the element in a particular food. Table I gives the $\mathrm{Zn}$ and energy content of the main components of the weekly diet for a family of four in the West of Scotland. If the $\mathrm{Zn}$ content alone is quoted for a foodstuff, then comments such as 'garden vegetables and fruits have a relatively low zinc content' (Sandstead, I973), mislead because leafy vegetables have a high $\mathrm{Zn}$ content/J and are a good source of trace elements if eaten in sufficient quantity.

The adult male requires, on average, food that provides $\mathrm{I} \cdot 24 \mu \mathrm{g} \mathrm{Zn} / \mathrm{kJ}$ in order to obtain $15 \mathrm{mg} \mathrm{Zn}$ and at the same time avoid exceeding the recommended energy intake. The value for the West of Scotland diet is $0.81 \mu \mathrm{g} \mathrm{Zn} / \mathrm{kJ}$. The only items which reach or exceed the recommended value are meats, beverages (mainly the result of tea), nuts, leafy vegetables, eggs and milk. Of these, only the leafy vegetables have a sufficient value for $\mathrm{Zn}$ : energy to increase significantly the average value of $0.8 \mathrm{r} \mu \mathrm{g} / \mathrm{kJ}$. The adult diet is deficient by $4900 \mu \mathrm{g}$; thus if I MJ (approximately $3 \mathrm{~kg}$ ) of cabbage $(5 \mu \mathrm{g} \mathrm{Zn} / \mathrm{kJ})$ is consumed at the expense of the I MJ of a low- $\mathrm{Zn}$ food then the diet would be brought into the recommended $\mathrm{Zn}$-energy balance - but no one would enjoy eating a $3 \mathrm{~kg}$ cabbage every day. An alternative is to supplement the diet with inorganic $\mathrm{Zn}$. Inorganic $\mathrm{Zn}$ has been administered with success to patients with chronic Zn deficiency (Prasad et al. 1963) and to cardiovascular disease patients (Pories et al. 1967). However, it is doubtful if the design of the human metabolism could include a requirement for an inorganic $\mathrm{Zn}$ supplement. In any case the ingestion of inorganic $\mathrm{Zn}$ over prolonged periods of time is likely to upset the balance of $\mathrm{Zn}$ with other essential trace elements.

From the dietary information obtained for the West of Scotland the daily family intake of white flour is estimated to be approximately $0.53 \mathrm{~kg}$. White flour has had approximately $800 \mathrm{~g} \mathrm{Zn} / \mathrm{kg}$ removed during the refining process (Schroeder, 1971). Thus if unrefined (i.e. $100 \%$ wholemeal) flour is used exclusively in the diet, then the adult male could increase his intake of $\mathrm{Zn}$ by approximately $3.5 \mathrm{mg} / \mathrm{d}$ and thereby achieve the RDA of $15 \mathrm{mg}$. The children would similarly achieve their respective RDA.

The RDA for pregnant, lactating and adult women present a particular problem. The 'average' adult woman, if married and eating the same diet as her husband, can never achieve her RDA. The pregnant or lactating woman is in an even less favourable position and must find an additional $5 \mathrm{mg}$ and $10 \mathrm{mg} \mathrm{Zn}$ respectively with corresponding increases of $I \cdot 3$ and $2 \cdot I$ MJ. The lactating woman must therefore look for a food source providing approximately $5 \mu \mathrm{g} \mathrm{Zn} / \mathrm{kJ}$. The only apparent solution to this is an inorganic $\mathrm{Zn}$ supplement.

\section{CONCLUSION}

The West of Scotland diet contains less $\mathrm{Zn}$ than the recommended daily allowance. This either indicates the need for a revision of the allowances or suggests that a change of diet is necessary. The change could be made simply by the substitution of wholemeal flour for the presently preferred white flour. Other changes in diet could be used but they are unlikely to be acceptable. Even with these changes the requirement of pregnant or lactating women is unlikely to be met and the recommended allowances must either be at fault or these women must have a temporary deficiency as part of their condition.

Over all the study shows that there is no room for complacency about the position of 


\section{I6 T. D. Lyon, H. Smith and Laura B. Smith}

essential trace elements in the diet and that the suggested dietary requirements must be made on a sound basis.

\section{REFERENCES}

Evans, G. N. \& Johnstone, P. E. (1977). Am. J. clin. Nutr. 30, 873.

Food and Nutrition Board (1970). Proc. Workshop Natn. Res. Coun. Zinc in Hum. Nutr. Washington, DC: National Academy of Sciences.

National Academy of Sciences (1974). Recommended Dietary Allowances, 8th ed. Washington, DC: National Academy of Sciences.

O'Dell, B. L., Burpo, C. E. \& Savage, J. E. (1972). J. Nutr. roz, 653.

Pories, W. J., Henzel, J. H., Rob, C. G. \& Strain, W. H. (1967). Lancet ii, I 2 I.

Prasad, A. S. (1966). Zinc Metabolism. Illinois: Thomas Springfield.

Prasad, A. S., Schulert, A. R., Miale, A., Farid, Z. \& Sandstead, H. H. (1963). J. Lab. clin. Med. 61, 537.

Reinhold, J. G., Nasr, K., Lahimgarzadeh, A. \& Hedayati, H. (1973). Lancet i, 283.

Sandstead, H. H. (1973). Am. J. clin. Nutr. 26, 1251.

Schroeder, H. A. (197I). Am. J. clin. Nutr. 24, 562.

Schroeder, H. A. (1974). The Poisons Around Us. Bloomington, Indiana: University Press.

Scott, R. O., Mitchell, R. L., Purves, D. \& Voss, R. C. (197I). Spectrochemical Methods of Analysis. Aberdeen: Waverley Press.

Underwood, E. J. (1971). Trace Elements in Human and Animal Nutrition, 3rd ed. New York: Academic Press.

White, H. S. \& Gynne, T. N. (1971). J. Am. Dent. Soc. 59, 27. 